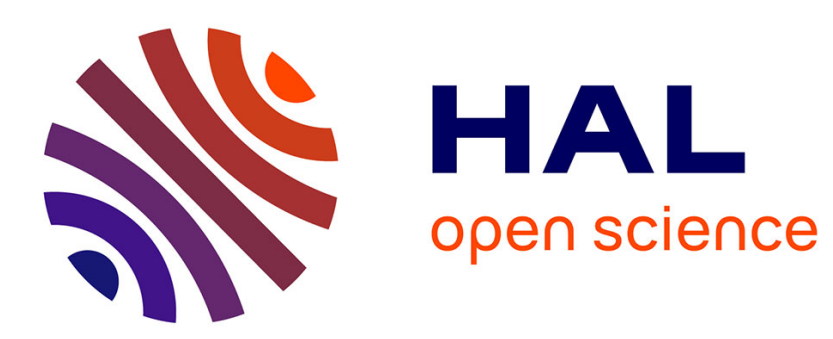

\title{
Immunological considerations regarding parental concerns on pediatric immunizations
}

Francesco Nicoli, Victor Appay

\section{To cite this version:}

Francesco Nicoli, Victor Appay. Immunological considerations regarding parental concerns on pediatric immunizations. Vaccine, 2017, 35 (23), pp.3012 - 3019. 10.1016/j.vaccine.2017.04.030 . hal01529332

\section{HAL Id: hal-01529332 \\ https://hal.sorbonne-universite.fr/hal-01529332}

Submitted on 30 May 2017

HAL is a multi-disciplinary open access archive for the deposit and dissemination of scientific research documents, whether they are published or not. The documents may come from teaching and research institutions in France or abroad, or from public or private research centers.
L'archive ouverte pluridisciplinaire HAL, est destinée au dépôt et à la diffusion de documents scientifiques de niveau recherche, publiés ou non, émanant des établissements d'enseignement et de recherche français ou étrangers, des laboratoires publics ou privés. 


\section{Immunological considerations regarding parental concerns on pediatric}

\section{2 immunizations}

3 Francesco Nicolia, ${ }^{a, b}$ Victor Appay ${ }^{a, b}$

4 a Sorbonne Universités, UPMC Univ Paris 06, DHU FAST, CR7, Centre d'Immunologie et des Maladies

5 Infectieuses (CIMI-Paris), Paris, France

6 b INSERM, U1135, CIMI-Paris, Paris, France

7 Correspondance to

8 Francesco Nicoli, Centre d'Immunologie et des Maladies Infectieuses (CIMI-Paris), 91 bd de I'Hopital, 75013

$9 \quad$ Paris, France. E-mail address: francesco.nicoli@upmc.fr. 


\section{Abstract}

13 Despite the fundamental role of vaccines in the decline of infant mortality, parents may decide to decline 14 vaccination for their own children. Many factors may influence this decision, such as the belief that the infant 15 immune system is weakened by vaccines, and concerns have been raised about the number of vaccines and the 16 early age at which they are administered. Studies focused on the infant immune system and its reaction to

17 immunizations, summarized in this review, show that vaccines can overcome those suboptimal features of infant immune system that render them more at risk of infections and of their severe manifestations. In addition, many vaccines have been shown to improve heterologous innate and adaptive immunity resulting in lower mortality rates for fully vaccinated children. Thus, multiple vaccinations are necessary and not dangerous, as infants can respond to several antigens as well as when responding to single stimuli. Current immunization schedules have been developed and tested to avoid vaccine interference, improve benefits and reduce side effects compared to single administrations. The infant immune system is therefore capable, early after birth, of managing several antigenic challenges and exploits them to prompt its development.

\section{5}

29 Key words: vaccine; children; heterologous effect; pediatric immunization. 
Despite the fundamental role of vaccines in the decline of infant mortality [1], the decision of vaccinating one's own children is often made with some anxiety [2]. Concerns are varied and include the safety of single vaccine components, the age at first immunization (i.e. too early) or the number of vaccines (i.e. too many) [2]. Severe adverse reactions are extremely rare [3], but parents may have more general worries regarding the capacity of such a young immune system to bear immunizations. The aim of this review is to summarize key concepts of human immunology and vaccinology to understand the reaction of the early age immune system to vaccines.

\section{Vaccine-specific immune responses in children}

\subsection{Development of vaccine-specific immunity}

The development of adaptive memory responses, which are the primary target of immunizations, needs the initial triggering by innate cells such as professional antigen presenting cells (APC). However, this step is defective in early age [4]: newborn antigen presenting cells are low in number, immature, respond poorly to activation via Pattern Recognition Receptors (PRR) and provide modest co-stimulation [Reviewed in 5, 6]. As a consequence, primary CD8 and CD4 responses may be weaker [Reviewed in 7, 8] and show a bias toward a Th2 phenotype [Reviewed in 7, 8], which is then reverted through booster doses and adjuvants $[9,10]$. Nevertheless, the development of a memory pool is not prevented, even in subjects with undetectable effector responses [11].

The immaturity of secondary lymphoid organs $[12,13]$ limits the development of humoral responses at early age, which are lower in magnitude and shorter in duration [Reviewed in 14]. Nonetheless, the development of memory B cells is not compromised and may occur even in subjects with low antibody titers $[15,16]$. In addition, infants below the third month of age are unable to generate antibody responses against those 
antigens that do not require T cell help (e.g. polysaccharides) [17, 18], a problem overcome through their conjugation with proteins [19].

The overall immaturity of infant immune system (summarized in Fig. 1 and Table S1), which was necessary to ensure maternofetal tolerance [18], results in lower vaccine responses than those developed in adults [20], save some relevant exceptions [21-23]. However, the primary aim of pediatric vaccines is not to develop adultlike immune responses (which will be reached through boosting doses [24, 25]), but rather to induce protective immunity, and data show that protective antibody titers may be elicited in more than $90 \%$ of children at 7 months of age against individual immunogens such as Polio, diphtheria-tetanus-pertussis (DTP), haemophilus influenzae type B (Hib), Hepatitis B virus (HBV) and Pneumococcal conjugate vaccine (PCV) [26]. Indeed, newborns can still develop innate and adaptive responses against the enormous number of microorganisms met since the delivery or even in utero [27-29] and vaccine-specific B and T immune responses already within hours after birth [30,31], demonstrating that even if some immune functions may be suboptimal in early age, they are sufficiently developed to mount protective responses and generate effective memory cells $[11,15$, 16], the final targets of vaccines. In addition, adjuvants and formulation efforts may help an immature immune system to develop vaccine-specific responses that would not be elicited by natural infections [19].

\subsection{Indirect effects of vaccine-specific immunity}

The importance of vaccine-specific responses goes beyond the simple prevention of the infections targeted by the immunization (Table 1). For instance, vaccine-induced epitope-specific responses towards one virus may show cross protection against other viral genotypes [32] or viruses of the same family [33]. Prevention of heterologous infections also occurs by avoiding the immunosuppressive effects exerted by pathogens such as varicella, influenza or measles [34-36]. Vaccine-preventable infections are often involved in other pathologies; for instance, respiratory infections and Bordetella pertussis contribute to sudden infant death syndrome (SIDS) [37-39]. Indeed, whilst several modifiable (e.g. sleeping position, type of bed and bedclothes) and non- 
modifiable (e.g. genetic) risk factors are associated with SIDS [38], its incidence is lowered after vaccination against DTP, Hib and pneumococcal bacteria [39-41].

\section{Non-specific immune responses elicited by vaccines}

Several studies have shown that exposure to infectious agents may alter the immune response to unrelated infections [42]. Consistently, vaccines have been shown to affect, on a long term temporal frame, innate immunity (that has recently shown memory-like properties referred to as "trained immunity") as well as adaptive immunity toward unrelated antigens $[43,44]$.

\subsection{Adjuvant effect}

Bacillus Calmette-Guérin (BCG) vaccine induces a strong polyclonal stimulation, boosts APC and lymphocyte functions [44-46] and increases responses toward vaccines administered at the same moment [47] or even later $[48,49]$. In addition, BCG vaccine is used as an immunotherapeutic treatment against cancer and has been shown to prevent lymphoma and leukemia $[45,50]$.

\subsection{Effect towards heterologous infections}

BCG and, most likely, measles-mumps-rubella (MMR) vaccines favor the development of macrophage and monocyte functions $[44,51,52]$ as well as lymphocyte responses $[44,48,52,53]$. This has been associated with a lower incidence of infections [54-56], particularly at the level of the respiratory tract [57-59]. Conversely, alum-adjuvanted DTP vaccines induce preferentially Th2-responses $[60,61]$ and are associated with increased susceptibility to infections $[54,55,62]$. However, this effect is controversial, as some studies found a protective role or a lack of association $[57,63,64]$.

\subsection{Effect on atopic disorders and autoimmune diseases}

Historically, vaccines have been proposed to be involved in the development of allergies, asthma and other atopic disorders [65]. However, while this association has not been confirmed [66-68], it has been shown that 
protection towards heterologous respiratory infections through direct and indirect mechanisms may decrease the risk of asthma, in particular with $\operatorname{MMR}[69,70]$ and $B C G[71,72]$ vaccines. Moreover, as atopic disorders are associated with Th2-type responses [73], vaccines favoring a Th1 phenotype (such as BCG or MMR) might be protective [72]. Conversely, although some studies found also a protective role for inactivated vaccines [68, 74], others reported lack of association or even a negative effect $[75,76]$.

Vaccines have also been considered as potential causes of autoimmune diseases (AIDs), in particular due to adjuvants responsible for the "autoimmune/inflammatory syndrome induced by adjuvants" (ASIA) [77, 78]. This topic is quite controversial: while case reports were published $[77,78]$, cohort studies showed a lack of association between vaccinations and AIDs [79].

\subsection{Effect on overall mortality}

The capacity of some vaccines (i.e. BCG [80-82], MMR [80, 82], Smallpox [83] and Polio [84] vaccines) to prevent unrelated infections results in a lower mortality rate. Conversely, it has been proposed that DTP vaccine might be associated with a higher mortality rate, although results are not consistent between studies $[56,80,82,85-90]$. WHO concluded that evidence is insufficient to support any association of DTP vaccine with overall mortality [82].

\section{Concerns leading to "personalized" immunization schedules}

The fear that infant immune system may be weakened by vaccines leads to "personalized" immunization schedules where vaccines against those diseases believed not so harmful or easy to contract are delayed or avoided. This attitude jeopardizes the health of children for all their lifetime [91, 92], as well as of the community where they live [93], including the grandparents [94], newborn siblings [95] and the mother herself [92]. 


\subsection{Are vaccines weakening the immune system?}

121 The above reported scientific evidence (summarized in Tables 1 and S2) argues against a deleterious effect of

122 vaccines on the infant immune system, showing rather that vaccines behave as other environmental factors

123 (microbes or nutrients), in accordance with the hygiene hypothesis, favoring the development of the immune

124 system [96, 97]. Indeed, children with complete vaccination coverage show, compared to unvaccinated or

125 poorly vaccinated pairs, a lower mortality rate and a general better health status [98-102].

\section{$126 \quad 4.2$ My child is so young, should I delay vaccinations?}

127 Current vaccination schedules, although they may vary between countries, recommend immunizations directly after birth with HBV and BCG vaccines (and eventually oral polio vaccine, OPV), and at 2 months with DTP, Hib, PCV, rotavirus vaccine (RV) and inactivated polio vaccine (IPV). Often parents prefer to postpone immunizations to wait for a "more mature" immune system [103]. This may leave children unimmunized for years. Indeed, while the immune system rapidly develops some functions at the time of first dose, i.e. twothree months after birth $[18,104,105]$, other properties (such as balanced IgG1 and IgG2 production) may reach adult-levels at 1 year $[104,106,107]$ or even during adolescence, as in the case of IL12 production [104, $108,109]$. In addition, the suboptimal features of the infant immune system that may argue against early life vaccination are the same that render infants more susceptible to infections $[6,110]$ : natural infections induce, in infants, poor Th1 and T-independent antibody responses which are instead elicited by vaccines [10, 19, 111]. Thus, postponing the first dose of vaccines: i) may have low to no effect on immunogenicity [112]; ii) may increase the risks of adverse events [113], of never completing the vaccination course $[103,114]$ and of modifying the order of immunizations with possible negative health outcomes [57, 115]; iii) and, most of all, will leave children unprotected in a very risky period. For instance, a delay in initiating the diphtheria-tetanusacellular pertussis (DTaP) immunization program may double hospitalizations [116-118] as the first dose

142 administered at 2 months of age already confers considerable protection (from $50 \%$ to $75 \%$ or more) [118$143120]$. 


\section{$144 \quad 4.3$ Are multiple immunizations overwhelming the immune system?}

145 Co-administration of vaccines is possible in two ways: combined vaccination (several antigens formulated in one single vaccine) and simultaneous administration (more than one vaccine is administered concurrently but

147 at different anatomic sites). Simultaneous administration may be less compliant [121] compared to combined

148 vaccination, but it lowers the risk of interference between vaccines [122]. The latter may be positive, as for

149 vaccines comprising antigens and adjuvants at the same time $[21,47,123]$, or negative, as was shown with the combination of MMR and varicella vaccines (MMRV) [124]. This specific problem was later solved, mostly by changing the doses of single components, to achieve for MMRV vaccine administration the same level of immunogenicity as when MMR and varicella vaccines are administered separately [125]. Vaccines may interfere at the level of the formulation or, when injected, at the level of immune responses, for instance through polyclonal stimulation by one component or competition for cross-specific responses. It has been proposed that live vaccines should be administered with a minimum of 28 days of time gap [122] to avoid negative interferences [126]; however, this concept has been challenged in some studies [127, 128].

Conversely, negative interferences seem not to affect inactivated vaccines $[129,130]$.

Current immunization schedules are tested to avoid vaccine-specific interactions and show that infants may efficiently respond to up to 10 vaccines (each of them composed of several antigens) at the same time [131, 132]. This demonstrates that multiple vaccinations do not exhaust immune resources, and are a safe practice [133]. This concept is proved in children with mild diseases that have comparable vaccine responses as healthy pairs [134-136]. Indeed, the huge repertoire of B- and T- cell specificity renders the immune system capable of recognizing and facing different threats at the same time. It has been assumed that as much as 11 vaccines given at the same time will exploit only the $0.1 \%$ of the B cell response [137]. 


\section{Conclusion}

166 The tremendous benefits that immunizations have on children's health may be undermined by personal risky

167 choices (not doing or delaying vaccinations) driven by some misconceptions such as: i) underestimating life

168 threatening diseases or the functionality of an early age immune system; ii) overestimating vaccine side effects.

169 Complete and reliable lists of adverse events connected to immunizations may be easily found (Box 1) to

170 inform parents. Conversely, the understanding of the interaction between the early age immune system and

171 vaccines is a more complex issue that involves several notions of immunology and vaccinology, and inadequate

172 answers to parents' doubts on these topics may have deleterious effects on immunization programs. Parents

173 should be reassured by current evidence demonstrating direct and indirect benefits of vaccines, such as a

174 decrease in overall morbidity and mortality from pediatric age, and a positive role in the development of the

175 immune system (Table 1). The knowledge of these indirect effects, the awareness of the threats that some

176 vaccine-preventable diseases pose especially in early age, and a correct understanding of infant immunity may

177 thus provide the basis to avoid the counterproductive decision of underimmunization (such as delaying

178 vaccinations or avoiding multiple immunizations, see Table 2). This decision, although taken with the good

179 intention to safeguard one's own children, may easily put at risk their life and the health of surrounding 180 people.

181

182

183 


\section{Conflict of interest statement}

185 None.

186

\section{Acknowledgements}

188 This work was supported by the French Agence Nationale de la Recherche (ANR; projectANR-14-CE14-0030-

189 01). We would like to thank Justin Frere for editorial assistance. 


\section{References}

191 [1] Lernout T, Theeten H, Leuridan E, Van Damme P. Do vaccines save lives? Yes they do! Acta Med Port $192 \quad 2014 ; 27: 160-2$.

193 [2] Alfredsson R, Svensson E, Trollfors B, Borres MP. Why do parents hesitate to vaccinate their children against 194 measles, mumps and rubella? Acta Paediatr 2004;93:1232-7.

195 [3] Maglione MA, Das L, Raaen L, Smith A, Chari R, Newberry S, et al. Safety of vaccines used for routine 196 immunization of U.S. children: a systematic review. Pediatrics 2014;134:325-37.

197 [4] Matthews NC, Wadhwa M, Bird C, Borras FE, Navarrete CV. Sustained expression of CD154 (CD4OL) and 198 proinflammatory cytokine production by alloantigen-stimulated umbilical cord blood T cells. J Immunol $199 \quad 2000 ; 164: 6206-12$.

200 [5] Kollmann TR, Levy O, Montgomery RR, Goriely S. Innate immune function by Toll-like receptors: distinct 201 responses in newborns and the elderly. Immunity 2012;37:771-83.

202 [6] Levy O. Innate immunity of the newborn: basic mechanisms and clinical correlates. Nat Rev Immunol $203 \quad 2007 ; 7: 379-90$.

204 [7] Marchant A, Goldman M. T cell-mediated immune responses in human newborns: ready to learn? Clin Exp 205 Immunol 2005;141:10-8.

206 [8] Adkins B, Leclerc C, Marshall-Clarke S. Neonatal adaptive immunity comes of age. Nat Rev Immunol $207 \quad 2004 ; 4: 553-64$.

208 [9] Rieber N, Graf A, Hartl D, Urschel S, Belohradsky BH, Liese J. Acellular pertussis booster in adolescents 209 induces Th1 and memory CD8+ T cell immune response. PLoS One 2011;6:e17271.

210 [10] Barrios C, Brandt C, Berney M, Lambert PH, Siegrist CA. Partial correction of the TH2/TH1 imbalance in 211 neonatal murine responses to vaccine antigens through selective adjuvant effects. Eur J Immunol 212 1996;26:2666-70. 
213 [11] Ausiello CM, Lande R, Urbani F, la Sala A, Stefanelli P, Salmaso S, et al. Cell-mediated immune responses in

214 four-year-old children after primary immunization with acellular pertussis vaccines. Infect Immun

215 1999;67:4064-71.

216 [12] Kruschinski C, Zidan M, Debertin AS, von Horsten S, Pabst R. Age-dependent development of the splenic

217 marginal zone in human infants is associated with different causes of death. Hum Pathol 2004;35:113-21.

218 [13] Pihlgren M, Tougne C, Bozzotti P, Fulurija A, Duchosal MA, Lambert PH, et al. Unresponsiveness to

219 lymphoid-mediated signals at the neonatal follicular dendritic cell precursor level contributes to delayed

220 germinal center induction and limitations of neonatal antibody responses to T-dependent antigens. J Immunol

$221 \quad 2003 ; 170: 2824-32$.

222 [14] Siegrist CA, Aspinall R. B-cell responses to vaccination at the extremes of age. Nat Rev Immunol

$223 \quad 2009 ; 9: 185-94$.

224 [15] Kakoulidou M, Ingelman-Sundberg H, Johansson E, Cagigi A, Farouk SE, Nilsson A, et al. Kinetics of antibody 225 and memory B cell responses after MMR immunization in children and young adults. Vaccine 2013;31:711-7.

226 [16] Amanna IJ, Carlson NE, Slifka MK. Duration of humoral immunity to common viral and vaccine antigens. N

227 Engl J Med 2007;357:1903-15.

228 [17] Rijkers GT, Dollekamp EG, Zegers BJ. The in vitro B-cell response to pneumococcal polysaccharides in 229 adults and neonates. Scand J Immunol 1987;25:447-52.

230 [18] Gervassi AL, Horton H. Is infant immunity actively suppressed or immature? Virology (Auckl) 2014;2014:1-

2319.

232 [19] Eskola J, Kayhty H. Early immunization with conjugate vaccines. Vaccine 1998;16:1433-8.

233 [20] Siegrist CA. The challenges of vaccine responses in early life: selected examples. J Comp Pathol 2007;137

234 Suppl 1:S4-9.

235 [21] Ota MO, Vekemans J, Schlegel-Haueter SE, Fielding K, Whittle H, Lambert PH, et al. Hepatitis B

236 immunisation induces higher antibody and memory Th2 responses in new-borns than in adults. Vaccine

$237 \quad 2004 ; 22: 511-9$. 
[22] Vekemans J, Ota MO, Wang EC, Kidd M, Borysiewicz LK, Whittle H, et al. T cell responses to vaccines in infants: defective IFNgamma production after oral polio vaccination. Clin Exp Immunol 2002;127:495-8.

[23] Ritz N, Strach M, Yau C, Dutta B, Tebruegge M, Connell TG, et al. A comparative analysis of polyfunctional T cells and secreted cytokines induced by Bacille Calmette-Guerin immunisation in children and adults. PLoS One 2012;7:e37535.

[24] Gans H, Yasukawa L, Rinki M, DeHovitz R, Forghani B, Beeler J, et al. Immune responses to measles and mumps vaccination of infants at 6, 9, and 12 months. J Infect Dis 2001;184:817-26.

[25] Fadugba OO, Wang L, Chen Q, Halasa NB. Immune responses to pertussis antigens in infants and toddlers after immunization with multicomponent acellular pertussis vaccine. Clin Vaccine Immunol 2014;21:1613-9. [26] Knuf M, Habermehl P, Cimino C, Petersen G, Schmitt HJ. Immunogenicity, reactogenicity and safety of a 7valent pneumococcal conjugate vaccine (PCV7) concurrently administered with a DTPa-HBV-IPV/Hib combination vaccine in healthy infants. Vaccine 2006;24:4727-36.

[27] Karlsson $\mathrm{H}$, Hessle $\mathrm{C}$, Rudin A. Innate immune responses of human neonatal cells to bacteria from the normal gastrointestinal flora. Infect Immun 2002;70:6688-96.

[28] Marchant A, Appay V, Van Der Sande M, Dulphy N, Liesnard C, Kidd M, et al. Mature CD8(+) T lymphocyte response to viral infection during fetal life. J Clin Invest 2003;111:1747-55.

[29] Huygens A, Lecomte S, Tackoen M, Olislagers V, Delmarcelle Y, Burny W, et al. Functional Exhaustion Limits CD4+ and CD8+ T-Cell Responses to Congenital Cytomegalovirus Infection. J Infect Dis 2015;212:484-94. [30] Wong VC, Ip HM, Reesink HW, Lelie PN, Reerink-Brongers EE, Yeung CY, et al. Prevention of the HBsAg carrier state in newborn infants of mothers who are chronic carriers of HBsAg and HBeAg by administration of hepatitis-B vaccine and hepatitis-B immunoglobulin. Double-blind randomised placebo-controlled study. Lancet 1984;1:921-6.

[31] Vekemans J, Amedei A, Ota MO, D'Elios MM, Goetghebuer T, Ismaili J, et al. Neonatal bacillus CalmetteGuerin vaccination induces adult-like IFN-gamma production by CD4+ T lymphocytes. Eur J Immunol 2001;31:1531-5. 
[32] Sandbulte MR, Jimenez GS, Boon AC, Smith LR, Treanor JJ, Webby RJ. Cross-reactive neuraminidase

264 antibodies afford partial protection against H5N1 in mice and are present in unexposed humans. PLoS Med $265 \quad 2007 ; 4:$ e59.

266 [33] Mansfield KL, Horton DL, Johnson N, Li L, Barrett AD, Smith DJ, et al. Flavivirus-induced antibody cross267 reactivity. J Gen Virol 2011;92:2821-9.

268 [34] Laupland KB, Davies HD, Low DE, Schwartz B, Green K, McGeer A. Invasive group A streptococcal disease in 269 children and association with varicella-zoster virus infection. Ontario Group A Streptococcal Study Group.

270 Pediatrics 2000;105:E60.

271 [35] O'Brien KL, Walters MI, Sellman J, Quinlisk P, Regnery H, Schwartz B, et al. Severe pneumococcal 272 pneumonia in previously healthy children: the role of preceding influenza infection. Clin Infect Dis 2000;30:7842739.

274 [36] Mina MJ, Metcalf CJ, de Swart RL, Osterhaus AD, Grenfell BT. Long-term measles-induced 275 immunomodulation increases overall childhood infectious disease mortality. Science 2015;348:694-9.

276 [37] Blood-Siegfried J. The role of infection and inflammation in sudden infant death syndrome.

277 Immunopharmacol Immunotoxicol 2009;31:516-23.

278 [38] Kinney HC, Thach BT. The sudden infant death syndrome. N Engl J Med 2009;361:795-805.

279 [39] Essery SD, Raza MW, Zorgani A, MacKenzie DA, James VS, Weir DM, et al. The protective effect of 280 immunisation against diphtheria, pertussis and tetanus (DPT) in relation to sudden infant death syndrome.

281 FEMS Immunol Med Microbiol 1999;25:183-92.

282 [40] Vennemann MM, Hoffgen M, Bajanowski T, Hense HW, Mitchell EA. Do immunisations reduce the risk for SIDS? A meta-analysis. Vaccine 2007;25:4875-9.

284 [41] Toro K, Meszaros R, Meszaros A, Csukas Z. Change in immunisation schedule and sudden infant death 285 syndrome in Hungary. FEMS Immunol Med Microbiol 2004;42:119-24. [42] Muraille E. The unspecific side of acquired immunity against infectious disease: causes and consequences. 
288

289

290

291

292

293

294

295

296

297

298

299

300

301

302

303

304

305

306

307

308

309

310

311

312

[43] Flanagan KL, van Crevel R, Curtis N, Shann F, Levy O, Optimmunize N. Heterologous ("nonspecific") and sex-differential effects of vaccines: epidemiology, clinical trials, and emerging immunologic mechanisms. Clin Infect Dis 2013;57:283-9.

[44] Kleinnijenhuis J, Quintin J, Preijers F, Benn CS, Joosten LA, Jacobs C, et al. Long-lasting effects of BCG vaccination on both heterologous Th1/Th17 responses and innate trained immunity. J Innate Immun 2014;6:152-8.

[45] Gandhi NM, Morales A, Lamm DL. Bacillus Calmette-Guerin immunotherapy for genitourinary cancer. BJU Int 2013;112:288-97.

[46] Ludwig AT, Moore JM, Luo Y, Chen X, Saltsgaver NA, O'Donnell MA, et al. Tumor necrosis factor-related apoptosis-inducing ligand: a novel mechanism for Bacillus Calmette-Guerin-induced antitumor activity. Cancer Res 2004;64:3386-90.

[47] Ota MO, Vekemans J, Schlegel-Haueter SE, Fielding K, Sanneh M, Kidd M, et al. Influence of Mycobacterium bovis bacillus Calmette-Guerin on antibody and cytokine responses to human neonatal vaccination. J Immunol 2002;168:919-25.

[48] Libraty DH, Zhang L, Woda M, Acosta LP, Obcena A, Brion JD, et al. Neonatal BCG vaccination is associated with enhanced T-helper 1 immune responses to heterologous infant vaccines. Trials Vaccinol 2014;3:1-5.

[49] Ritz N, Mui M, Balloch A, Curtis N. Non-specific effect of Bacille Calmette-Guerin vaccine on the immune response to routine immunisations. Vaccine 2013;31:3098-103.

[50] Villumsen M, Sorup S, Jess T, Ravn H, Relander T, Baker JL, et al. Risk of lymphoma and leukaemia after bacille Calmette-Guerin and smallpox vaccination: a Danish case-cohort study. Vaccine 2009;27:6950-8.

[51] Kleinnijenhuis J, Quintin J, Preijers F, Joosten LA, Ifrim DC, Saeed S, et al. Bacille Calmette-Guerin induces NOD2-dependent nonspecific protection from reinfection via epigenetic reprogramming of monocytes. Proc Natl Acad Sci U S A 2012;109:17537-42.

[52] Freyne B, Marchant A, Curtis N. BCG-associated heterologous immunity, a historical perspective: experimental models and immunological mechanisms. Trans R Soc Trop Med Hyg 2015;109:46-51. 
313 [53] Kleinnijenhuis J, Quintin J, Preijers F, Joosten LA, Jacobs C, Xavier RJ, et al. BCG-induced trained immunity

314 in NK cells: Role for non-specific protection to infection. Clin Immunol 2014;155:213-9.

315 [54] Valentiner-Branth P, Perch M, Nielsen J, Steinsland H, Garly ML, Fischer TK, et al. Community cohort study

316 of Cryptosporidium parvum infections: sex-differential incidences associated with BCG and diphtheria-tetanus-

317 pertussis vaccinations. Vaccine 2007;25:2733-41.

318 [55] Rodrigues A, Fischer TK, Valentiner-Branth P, Nielsen J, Steinsland H, Perch M, et al. Community cohort

319 study of rotavirus and other enteropathogens: are routine vaccinations associated with sex-differential

320 incidence rates? Vaccine 2006;24:4737-46.

321 [56] Sorup S, Benn CS, Poulsen A, Krause TG, Aaby P, Ravn H. Live vaccine against measles, mumps, and rubella

322 and the risk of hospital admissions for nontargeted infections. JAMA 2014;311:826-35.

323 [57] Hollm-Delgado MG, Stuart EA, Black RE. Acute lower respiratory infection among Bacille Calmette-Guerin

324 (BCG)-vaccinated children. Pediatrics 2014;133:e73-81.

325 [58] Stensballe LG, Nante E, Jensen IP, Kofoed PE, Poulsen A, Jensen H, et al. Acute lower respiratory tract

326 infections and respiratory syncytial virus in infants in Guinea-Bissau: a beneficial effect of BCG vaccination for

327 girls community based case-control study. Vaccine 2005;23:1251-7.

328 [59] Sorup S, Benn CS, Stensballe LG, Aaby P, Ravn H. Measles-mumps-rubella vaccination and respiratory syncytial virus-associated hospital contact. Vaccine 2015;33:237-45.

[60] Rowe J, Macaubas C, Monger TM, Holt BJ, Harvey J, Poolman JT, et al. Antigen-specific responses to

diphtheria-tetanus-acellular pertussis vaccine in human infants are initially Th2 polarized. Infect Immun 2000;68:3873-7.

[61] Brewer JM, Conacher M, Hunter CA, Mohrs M, Brombacher F, Alexander J. Aluminium hydroxide adjuvant initiates strong antigen-specific Th2 responses in the absence of IL-4- or IL-13-mediated signaling. J Immunol 1999;163:6448-54.

[62] Fischer JE, Johnson JE, Johnson TR, Graham BS. Pertussis toxin sensitization alters the pathogenesis of subsequent respiratory syncytial virus infection. J Infect Dis 2000;182:1029-38. 
338

339

340

341

342

343

344

345

346

347

348

349

350

351

352

353

354

355

356

357

358

359

360

361

362

[63] Storsaeter J, Olin P, Renemar B, Lagergard T, Norberg R, Romanus V, et al. Mortality and morbidity from invasive bacterial infections during a clinical trial of acellular pertussis vaccines in Sweden. Pediatr Infect Dis J 1988;7:637-45.

[64] Black SB, Cherry JD, Shinefield HR, Fireman B, Christenson P, Lampert D. Apparent decreased risk of invasive bacterial disease after heterologous childhood immunization. Am J Dis Child 1991;145:746-9. [65] McKeever TM, Lewis SA, Smith C, Hubbard R. Vaccination and allergic disease: a birth cohort study. Am J Public Health 2004;94:985-9.

[66] Gruber C, Illi S, Lau S, Nickel R, Forster J, Kamin W, et al. Transient suppression of atopy in early childhood is associated with high vaccination coverage. Pediatrics 2003;111:e282-8.

[67] DeStefano F, Gu D, Kramarz P, Truman BI, lademarco MF, Mullooly JP, et al. Childhood vaccinations and risk of asthma. Pediatr Infect Dis J 2002;21:498-504.

[68] Mullooly JP, Schuler R, Mesa J, Drew L, DeStefano F, team VSD. Wheezing lower respiratory disease and vaccination of premature infants. Vaccine 2011;29:7611-7.

[69] Hviid A, Melbye M. Measles-mumps-rubella vaccination and asthma-like disease in early childhood. Am J Epidemiol 2008;168:1277-83.

[70] Timmermann CA, Osuna CE, Steuerwald U, Weihe P, Poulsen LK, Grandjean P. Asthma and allergy in children with and without prior measles, mumps, and rubella vaccination. Pediatr Allergy Immunol

2015;26:742-9.

[71] Arnoldussen DL, Linehan M, Sheikh A. BCG vaccination and allergy: a systematic review and meta-analysis. J Allergy Clin Immunol 2011;127:246-53, 53 e1-21.

[72] El-Zein M, Parent ME, Benedetti A, Rousseau MC. Does BCG vaccination protect against the development of childhood asthma? A systematic review and meta-analysis of epidemiological studies. Int J Epidemiol 2010;39:469-86.

[73] Siegle JS, Hansbro N, Dong C, Angkasekwinai P, Foster PS, Kumar RK. Blocking induction of T helper type 2 responses prevents development of disease in a model of childhood asthma. Clin Exp Immunol 2011;165:19-28. 
363 [74] Bernsen RM, de Jongste JC, van der Wouden JC. Lower risk of atopic disorders in whole cell pertussis-

364 vaccinated children. Eur Respir J 2003;22:962-4.

365 [75] Nakajima K, Dharmage SC, Carlin JB, Wharton CL, Jenkins MA, Giles GG, et al. Is childhood immunisation associated with atopic disease from age 7 to 32 years? Thorax 2007;62:270-5.

367 [76] Spycher BD, Silverman M, Egger M, Zwahlen M, Kuehni CE. Routine vaccination against pertussis and the risk of childhood asthma: a population-based cohort study. Pediatrics 2009;123:944-50.

[77] Hawkes D, Benhamu J, Sidwell T, Miles R, Dunlop RA. Revisiting adverse reactions to vaccines: A critical appraisal of Autoimmune Syndrome Induced by Adjuvants (ASIA). J Autoimmun 2015;59:77-84. syndrome induced by adjuvants (ASIA): clues and pitfalls in the pediatric background. Immunol Res 2014;60:366-75.

[79] Schattner A. Consequence or coincidence? The occurrence, pathogenesis and significance of autoimmune manifestations after viral vaccines. Vaccine 2005;23:3876-86. 14.

[81] Aaby P, Kollmann TR, Benn CS. Nonspecific effects of neonatal and infant vaccination: public-health, immunological and conceptual challenges. Nat Immunol 2014;15:895-9.

[82] Higgins JPT, Soares-Weiser K, Reingold A. Systematic review of the non-specific effects of BCG, DTP and measles containing vaccines. http://www.who.int/immunization/sage/meetings/2014/april/3 NSE Epidemiology review Report to SAGE 14 Mar FINAL.pdf 2014.

384 [83] Jensen ML, Dave S, Schim van der Loeff M, da Costa C, Vincent T, Leligdowicz A, et al. Vaccinia scars associated with improved survival among adults in rural Guinea-Bissau. PLoS One 2006;1:e101. 
388

[85] Vaugelade J, Pinchinat S, Guiella G, Elguero E, Simondon F. Non-specific effects of vaccination on child survival: prospective cohort study in Burkina Faso. BMJ 2004;329:1309.

[86] Schurink-van't Klooster TM, Knol MJ, de Melker HE, van der Sande MA. Gender-specific mortality in DTPIPV- and MMR+/-MenC-eligible age groups to determine possible sex-differential effects of vaccination: an observational study. BMC Infect Dis 2015;15:148.

[87] Aaby P, Jensen H, Walraven G. Age-specific changes in the female-male mortality ratio related to the pattern of vaccinations: an observational study from rural Gambia. Vaccine 2006;24:4701-8.

[88] Benn CS, Aaby P. Diphtheria-tetanus-pertussis vaccination administered after measles vaccine: increased female mortality? Pediatr Infect Dis J 2012;31:1095-7.

[89] Aaby P, Nielsen J, Benn CS, Trape JF. Sex-differential and non-specific effects of routine vaccinations in a rural area with low vaccination coverage: an observational study from Senegal. Trans R Soc Trop Med Hyg 2015;109:77-84.

[90] Aaby P, Jensen H, Samb B, Cisse B, Sodemann M, Jakobsen M, et al. Differences in female-male mortality after high-titre measles vaccine and association with subsequent vaccination with diphtheria-tetanus-pertussis and inactivated poliovirus: reanalysis of West African studies. Lancet 2003;361:2183-8.

[91] Rosario-Rosario G, Gareca M, Kincaid H, Knouse MC. Using locally derived seroprevalence data on measles, mumps, rubella, and varicella by birth cohort to determine risks for vaccine-preventable diseases during international travel. J Travel Med 2015;22:396-402.

[92] Phalgune DS, Yervadekar RC, Sharma HJ, Dhere RM, Parekh SS, Chandak AO, et al. Sero-surveillance to assess rubella susceptibility and assessment of immunogenicity and reactogenicity of rubella vaccine in Indian girls aged 18-24 years. Hum Vaccin Immunother 2014;10:2813-8.

[93] Scarbrough Lefebvre CD, Terlinden A, Standaert B. Dissecting the indirect effects caused by vaccines into the basic elements. Hum Vaccin Immunother 2015;11:2142-57. 
411 [94] Miller E, Andrews NJ, Waight PA, Slack MP, George RC. Herd immunity and serotype replacement 4 years

412 after seven-valent pneumococcal conjugate vaccination in England and Wales: an observational cohort study.

$413 \quad$ Lancet Infect Dis 2011;11:760-8.

414 [95] Sugerman DE, Barskey AE, Delea MG, Ortega-Sanchez IR, Bi D, Ralston KJ, et al. Measles outbreak in a 415 highly vaccinated population, San Diego, 2008: role of the intentionally undervaccinated. Pediatrics $416 \quad 2010 ; 125: 747-55$.

417 [96] MacGillivray DM, Kollmann TR. The role of environmental factors in modulating immune responses in early 418 life. Front Immunol 2014;5:434.

419 [97] Daley D. The evolution of the hygiene hypothesis: the role of early-life exposures to viruses and microbes 420 and their relationship to asthma and allergic diseases. Curr Opin Allergy Clin Immunol 2014;14:390-6.

[98] McGovern ME, Canning D. Vaccination and all-cause child mortality from 1985 to 2011: global evidence 422 from the Demographic and Health Surveys. Am J Epidemiol 2015;182:791-8.

[99] Kristensen I, Aaby P, Jensen H. Routine vaccinations and child survival: follow up study in Guinea-Bissau,

West Africa. BMJ 2000;321:1435-8.

[100] Otto S, Mahner B, Kadow I, Beck JF, Wiersbitzky SK, Bruns R. General non-specific morbidity is reduced after vaccination within the third month of life--the Greifswald study. J Infect 2000;41:172-5. [101] Wilby KJ, Werry D. A review of the effect of immunization programs on antimicrobial utilization. Vaccine 2012;30:6509-14.

[102] Anekwe TD, Kumar S. The effect of a vaccination program on child anthropometry: evidence from India's Universal Immunization Program. J Public Health (Oxf) 2012;34:489-97. vaccine administration and timely childhood vaccination coverage. Public Health Rep 2010;125:534-41. 
435

436

437

438

439

440

441

442

443

444

445

446

447

448

449

450

451

452

453

454

455

456

457

458

459
[105] Krampera M, Vinante F, Tavecchia L, Morosato L, Chilosi M, Romagnani S, et al. Progressive polarization towards a T helper/cytotoxic type-1 cytokine pattern during age-dependent maturation of the immune response inversely correlates with CD30 cell expression and serum concentration. Clin Exp Immunol 1999;117:291-7.

[106] Clerici M, DePalma L, Roilides E, Baker R, Shearer GM. Analysis of T helper and antigen-presenting cell functions in cord blood and peripheral blood leukocytes from healthy children of different ages. J Clin Invest 1993;91:2829-36.

[107] Siegrist CA. Neonatal and early life vaccinology. Vaccine 2001;19:3331-46.

[108] Teig N, Moses D, Gieseler S, Schauer U. Age-related changes in human blood dendritic cell subpopulations. Scand J Immunol 2002;55:453-7.

[109] Upham JW, Lee PT, Holt BJ, Heaton T, Prescott SL, Sharp MJ, et al. Development of interleukin-12producing capacity throughout childhood. Infect Immun 2002;70:6583-8.

[110] Gantt S, Muller WJ. The immunologic basis for severe neonatal herpes disease and potential strategies for therapeutic intervention. Clin Dev Immunol 2013;2013:369172.

[111] Anderson P, Ingram DL, Pichichero ME, Peter G. A high degree of natural immunologic priming to the capsular polysaccharide may not prevent Haemophilus influenzae type b meningitis. Pediatr Infect Dis J 2000;19:589-91.

[112] Gans HA, Maldonado Y, Yasukawa LL, Beeler J, Audet S, Rinki MM, et al. IL-12, IFN-gamma, and T cell proliferation to measles in immunized infants. J Immunol 1999;162:5569-75.

[113] Hambidge SJ, Newcomer SR, Narwaney KJ, Glanz JM, Daley MF, Xu S, et al. Timely versus delayed early childhood vaccination and seizures. Pediatrics 2014;133:e1492-9.

[114] Guerra FA. Delays in immunization have potentially serious health consequences. Paediatr Drugs 2007;9:143-8.

[115] Aaby P, Ibrahim SA, Libman MD, Jensen $H$. The sequence of vaccinations and increased female mortality after high-titre measles vaccine: trials from rural Sudan and Kinshasa. Vaccine 2006;24:2764-71. 

pertussis in infants: unmatched case-control study. BMJ 2003;326:852-3.

[117] Glanz JM, Narwaney KJ, Newcomer SR, Daley MF, Hambidge SJ, Rowhani-Rahbar A, et al. Association between undervaccination with diphtheria, tetanus toxoids, and acellular pertussis (DTaP) vaccine and risk of pertussis infection in children 3 to 36 months of age. JAMA Pediatr 2013;167:1060-4.

[118] Nilsson L, Lepp T, von Segebaden K, Hallander H, Gustafsson L. Pertussis vaccination in infancy lowers the incidence of pertussis disease and the rate of hospitalisation after one and two doses: analyses of 10 years of pertussis surveillance. Vaccine 2012;30:3239-47. pertussis vaccine in infants. Pediatrics 2014;133:e513-9.

[120] Zamir CS, Dahan DB, Shoob H. Pertussis in infants under one year old: risk markers and vaccination status--a case-control study. Vaccine 2015;33:2073-8.

[121] Kaaijk P, Kleijne DE, Knol MJ, Harmsen IA, Ophorst OJ, Rots NY. Parents' attitude toward multiple vaccinations at a single visit with alternative delivery methods. Hum Vaccin Immunother 2014;10:2483-9. [122] General recommendations on immunization --- recommendations of the Advisory Committee on Immunization Practices (ACIP). MMWR Recomm Rep 2011;60:1-64. responses directed to the HIV-1 antigens Gag and Env: implications for the design of new vaccination strategies against AIDS. Vaccine 2008;26:727-37.

[124] White CJ, Stinson D, Staehle B, Cho I, Matthews H, Ngai A, et al. Measles, mumps, rubella, and varicella combination vaccine: safety and immunogenicity alone and in combination with other vaccines given to children. Measles, Mumps, Rubella, Varicella Vaccine Study Group. Clin Infect Dis 1997;24:925-31. varicella vaccine (Priorix-Tetra): immunogenicity and safety profile. Vaccine 2009;27:6504-11. 
484

485

486

487

488

489

490

491

492

493

494

495

496

497

498

499

500

501

502

503

504

505

506

507

508

[126] Nascimento Silva JR, Camacho LA, Siqueira MM, Freire Mde S, Castro YP, Maia Mde L, et al. Mutual interference on the immune response to yellow fever vaccine and a combined vaccine against measles, mumps and rubella. Vaccine 2011;29:6327-34.

[127] Stefano I, Sato HK, Pannuti CS, Omoto TM, Mann G, Freire MS, et al. Recent immunization against measles does not interfere with the sero-response to yellow fever vaccine. Vaccine 1999;17:1042-6. [128] Adu FD, Omotade OO, Oyedele OI, Ikusika O, Odemuyiwa SO, Onoja AL. Field trial of combined yellow fever and measles vaccines among children in Nigeria. East Afr Med J 1996;73:579-82.

[129] Kanra G, Silier T, Yurdakok K, Yavuz T, Baskan S, Ulukol B, et al. Immunogenicity study of a combined diphtheria, tetanus, acellular pertussis, inactivated poliomyelitis vaccine used to reconstitute a freeze-dried Haemophilus influenzae type b vaccine (DTaP-IPV//PRP-T) administered simultaneously with a hepatitis B vaccine at two, three and four months of life. Vaccine 1999;18:947-54.

[130] Usonis V, Bakasenas V. Does concomitant injection of a combined diphtheria-tetanus-acellular pertussis hepatitis B virus - inactivated polio virus vaccine influence the reactogenicity and immunogenicity of commercial Haemophilus influenzae type b conjugate vaccines? Eur J Pediatr 1999;158:398-402.

[131] Shinefield H, Black S, Thear M, Coury D, Reisinger K, Rothstein E, et al. Safety and immunogenicity of a measles, mumps, rubella and varicella vaccine given with combined Haemophilus influenzae type b conjugate/hepatitis B vaccines and combined diphtheria-tetanus-acellular pertussis vaccines. Pediatr Infect Dis J 2006;25:287-92.

[132] Zepp F, Behre U, Kindler K, Laakmann KH, Pankow-Culot H, Mannhardt-Laakmann W, et al. Immunogenicity and safety of a tetravalent measles-mumps-rubella-varicella vaccine co-administered with a booster dose of a combined diphtheria-tetanus-acellular pertussis-hepatitis B-inactivated poliovirusHaemophilus influenzae type b conjugate vaccine in healthy children aged 12-23 months. Eur J Pediatr 2007;166:857-64.

[133] Iqbal S, Barile JP, Thompson WW, DeStefano F. Number of antigens in early childhood vaccines and neuropsychological outcomes at age 7-10 years. Pharmacoepidemiol Drug Saf 2013;22:1263-70. 
509 [134] Halsey NA, Boulos R, Mode F, Andre J, Bowman L, Yaeger RG, et al. Response to measles vaccine in

510 Haitian infants 6 to 12 months old. Influence of maternal antibodies, malnutrition, and concurrent illnesses. $\mathrm{N}$

511 Engl J Med 1985;313:544-9.

512 [135] Ndikuyeze A, Munoz A, Stewart J, Modlin J, Heymann D, Herrmann KL, et al. Immunogenicity and safety

513 of measles vaccine in ill African children. Int J Epidemiol 1988;17:448-55.

514 [136] Dennehy PH, Saracen CL, Peter G. Seroconversion rates to combined measles-mumps-rubella-varicella

515 vaccine of children with upper respiratory tract infection. Pediatrics 1994;94:514-6.

516 [137] Offit PA, Quarles J, Gerber MA, Hackett CJ, Marcuse EK, Kollman TR, et al. Addressing parents' concerns:

517 do multiple vaccines overwhelm or weaken the infant's immune system? Pediatrics 2002;109:124-9.

518

519 


\section{$520 \quad$ Figure Legends}

\section{Fig. 1. Early age antigen-specific immune response.}

522 Newborns have few APCs, which display an immature phenotype (1) and a low response to some TLR ligands

523 (2). This results in suboptimal antigen presentation ("signal 1", 3) and co-stimulation through surface receptors

524 ("signal 2", 4), as well as secretion of cytokines ("signal 3", 5), in particular IL-12. Understimulated CD4+ T cells

525 show therefore a poor effector response, biased towards a Th2 type (6). B-cell responses are also impaired: T-

526 cell independent humoral responses develop only several months after birth (7) and even T-cell dependent

527 ones are weak due to a low expression of co-stimulatory molecules (8) and a limited development of T follicular

528 helper cells (9). The IgG production is limited as plasmacells are poorly functional (10), and produced

529 antibodies show reduced affinity maturation and shorter lifespan, in addition to be mainly constrained to the

530 IgG1 subclass (11). Defects at the level of APCs and CD4 ${ }^{+}$T-cell activation result in lower effector CD8 responses

531 against some antigens (12), also due to higher levels of suppressive populations (13). Further details and

532 literature references are presented in Table S1. Abbreviations: APC: antigen presenting cell; TLR: toll like

533 receptor; PAMP: Pathogen-associated molecular pattern; PRR: pattern recognition receptor. 
536 Immune-related heterologous effects of vaccines. Proposed mechanisms and literature references are shown

\section{7 in Table S2}

\begin{tabular}{|c|l|}
\hline \multicolumn{1}{|c|}{ Factor } & Effects \\
$\begin{array}{c}\text { Susceptibility toward } \\
\text { unrelated infections }\end{array}$ & $\begin{array}{l}\text { BCG and MMR vaccines have been associated with lower risk of infections. } \\
\text { DTP vaccine has been associated in some studies with an increased susceptibility to } \\
\text { enteropathogens in girls but showed a protective effect against respiratory infections. }\end{array}$ \\
\hline SIDS & $\begin{array}{l}\text { BCG vaccine has been shown to improve responses toward vaccines administered at } \\
\text { the same moment or later, and is used as immunotherapeutic against cancer. }\end{array}$ \\
\hline AIDs & $\begin{array}{l}\text { Some vaccines, and in particular DTP, have been associated with a reduced incidence } \\
\text { of SIDS. }\end{array}$ \\
\hline Atopic disorder & $\begin{array}{l}\text { Clinical and cohort studies failed in finding an increased prevalence of AIDs in subjects } \\
\text { exposed to vaccines or adjuvants, suggesting that AIDs and ASIA are not generalized } \\
\text { phenomena. Further studies are necessary to assess frequency and mechanisms of } \\
\text { the reported cases. }\end{array}$ \\
\hline Overall mortality & $\begin{array}{l}\text { MMR and BCG vaccines have been shown in some studies to decrease the risk of } \\
\text { asthma. Conflicting results have been shown for DTP vaccine. }\end{array}$ \\
\hline $\begin{array}{l}\text { BCG, MMR, Smallpox and oral Polio vaccines have been associated with a lower } \\
\text { mortality rate. } \\
\text { DTP vaccine has been associated with either increased and decreased non-specific } \\
\text { mortality. However, current evidence is insufficient to support either of these } \\
\text { conclusions. }\end{array}$ \\
\hline
\end{tabular}

538

539 
541 Common questions regarding interaction between vaccines and early age immune system

\begin{tabular}{|c|c|c|}
\hline Questions & Reasons of Parents & Answer \\
\hline $\begin{array}{l}\text { May I decide to } \\
\text { do only part of } \\
\text { recommended } \\
\text { vaccinations? }\end{array}$ & $\begin{array}{l}\text { Some vaccine- } \\
\text { preventable-diseases } \\
\text { believed not so } \\
\text { harmful or easy to } \\
\text { contract }\end{array}$ & $\begin{array}{l}\text { This choice may have different harmful consequences: } \\
\text { - Leave children unprotected for underestimated } \\
\text { dangers. } \\
\text { - } \\
\text { Reverse the vaccination schedule with } \\
\text { detrimental effects on heterologous immunity. } \\
\text { - Weakening of the herd immunity } \rightarrow \text { negative } \\
\text { consequences for relatives (e.g. grandparents, } \\
\text { siblings too young to be vaccinated, pregnant } \\
\text { mothers) and immunocompromised persons. }\end{array}$ \\
\hline $\begin{array}{l}\text { Are vaccines } \\
\text { weakening the } \\
\text { immune } \\
\text { system? }\end{array}$ & $\begin{array}{l}\text { Fear of } \\
\text { immunosuppressive } \\
\text { effects of vaccines }\end{array}$ & $\begin{array}{l}\text { - Vaccines, in particular if administered on time } \\
\text { and according suggested immunization } \\
\text { schedules, favor the development of the } \\
\text { immune system, enhancing protection not only } \\
\text { against infections targeted by the } \\
\text { immunization, but also to unrelated microbes. }\end{array}$ \\
\hline $\begin{array}{l}\text { My child is so } \\
\text { young, should I } \\
\text { delay } \\
\text { vaccinations? }\end{array}$ & $\begin{array}{l}\text { Fear that early age } \\
\text { immune system may } \\
\text { be too frail }\end{array}$ & $\begin{array}{l}\text { - The immune system of infants, although not } \\
\text { fully mature, may easily bear the stimuli } \\
\text { provided by vaccines, which are relatively weak } \\
\text { if compared to the natural infections. } \\
\text { - Innate and adaptive immunity in young } \\
\text { children lack some specific functions that } \\
\text { render them more susceptible to infections } \\
\text { that, for the same reason, display high } \\
\text { morbidity and mortality rate at early age. } \\
\text { Vaccines are the only strategy to improve } \\
\text { protection against these threats. } \\
\text { For some vaccines, children may display adult- } \\
\text { like immune responses, even in early age. }\end{array}$ \\
\hline $\begin{array}{l}\text { Are multiple } \\
\text { immunizations } \\
\text { overwhelming } \\
\text { the immune } \\
\text { system? }\end{array}$ & $\begin{array}{l}\text { Fear of } \\
\text { overstimulating the } \\
\text { immune system }\end{array}$ & $\begin{array}{l}\text { - The immune system may develop strong and } \\
\text { competent antigen-specific immune response } \\
\text { to hundreds of unrelated antigens at the same } \\
\text { time. } \\
\text { - All licensed combined vaccination and } \\
\text { simultaneous administration of vaccines are } \\
\text { always tested to assess that the co- } \\
\text { administration is not inferior to administration } \\
\text { of single components. }\end{array}$ \\
\hline
\end{tabular}

